\title{
Sustainable forest management in a human dominated landscape and its implications for biodiversity conservation: a Nigerian lowland forest perspective
}

\author{
This article was published in the following Dove Press journal: \\ Research and Reports in Biodiversity Studies \\ 15 November 2013 \\ Number of times this article has been viewed
}

\author{
Rachel Ashegbofe Ikemeh \\ Southwest/Niger Delta Forest Project, \\ Abuja, Nigeria
}

\begin{abstract}
Biodiversity loss is often attributed to rapid human population growth, particularly in forest communities. Hence, various forms of forest management tend to merge conservation agendas with rural development objectives, giving birth to the global concept of Sustainable Forest Management. Biodiversity conservation and local livelihoods remain the two most critical factors in attaining sustainability, yet the balancing acts involved are complex and untenable in many forest areas. On one hand, biodiversity-conservation actions restricts access to biological resources, while on the other hand, some community development programs and economic growth agendas contribute immensely to biodiversity loss and species extinction. These two topical subject matters are compounded by other related issues, such as local/human rights, poverty, development needs, and particularly our rapidly increasing vulnerability to climate change. In reconciling these conflicts, sustainable forest-management practices attempt an integrated approach targeted at sustaining traditional means of livelihood and providing job opportunities for local people while encouraging the preservation of forest diversity. Within this context, the interplay of these two factors cannot be more complicated than in managing a unique forest zone within Africa's most populous nation - Nigeria. This paper reviews the interrelatedness and the complexities that exist between biodiversity conservation and local livelihoods; it scrutinizes their analogous underlying problems in Nigeria using the experiences, findings, anecdotal evidences, and observations made during surveys conducted in ten forest reserves within the Nigerian lowland forest ecoregion between 2006 and 2012. The aim of this paper is to draw attention to the region and the associated challenges of forest management in a human-dominated landscape that has an age-old tradition for bush-meat consumption, farming, and a pressing need to survive the upsurge of economic difficulties, political changes, and social limitations.
\end{abstract}

Keywords: forest management, biodiversity, Nigerian lowland forest, human population, deforestation

\section{Introduction}

The evolving concept of Sustainable Forest Management (SFM) presupposes that balance between demands for forest lands/resources and the preservation of forest diversity can be achieved using predetermined criteria and indicators to implement and evaluate this singular goal - the attainment of balance. The United Nations (UN) UN adopted what was considered by the Convention on Biological Diversity as the most widely agreed definition of SFM, which is that SFM as a dynamic and evolving concept aims to maintain and enhance the economic, social, and environmental value of all types of forests, for the benefit of present and future generations. ${ }^{1}$ As a result,
Correspondence: Rachel Ashegbofe lkemeh Southwest/Niger Delta Forest Project, PO Box 3565, Garki, Abuja 90000 I, Nigeria

Tel +2348I88202545

Email r.ashegbofe@gmail.com 
typical SFM practices often focus on integrated methods where human socioeconomic needs are being catered for, while at the same time preserving the biological resources of the forest, with "all things being equal." Incidentally, the very dynamics of man and growing human populations are factors that cannot remain the same; therefore, while the SFM concept will remain politically correct, in practical terms, forest managers will have to grapple with the immense pressure of an exploding human population and/or constantly evolving human exigencies alongside vanishing forest cover.

Nigeria is arguably one of the most biodiverse countries in the world, with about twelve major ecological zones (or ecoregions), each containing its unique composition of wild plants and animals. However, despite its extensive list of designated protected areas (nearly 950 forest/game reserves), many of these areas have been totally converted to other land use/cover types, and resident biodiversity species are either extinct or perilously low in numbers. With about 160 million people and an estimated growth rate of $2.3 \%$ per annum, ${ }^{2}$ Nigeria is Africa's most populous nation. As an oil-dependent economy, about $90 \%$ of the country's national income is generated from the petroleum industry operated within the Niger Delta and its vast swamp forest zone and coastal areas, where there has been devastating environmental pollution and forest degradation. However, despite the huge windfall in oil revenues, only an estimated $1 \%$ of the population benefits from much of the energy proceeds according to the Human Development Index (HDI) 2012 report. With more than half of its population living in poverty, many turn to the erstwhile most lucrative industry in the country prior to fossil fuels - agriculture. An estimated $70 \%$ of Nigerians have taken to farming as a means of livelihood, ${ }^{3}$ and this, besides the need for land to house the country's growing human numbers, in turn puts additional pressure on available land area for biodiversity conservation.

Only about $20 \%$ of the 923,768 square kilometers $\left(\mathrm{km}^{2}\right)$ land area covered by Nigeria is forest land. These forests are found mostly in the south of the country, except for patches of forest vegetation and gallery forests occurring in the Guinean forest-savanna mosaic and the Sudan-Guinea savanna ecoregions, which cover much of the central and northern parts of the country. Forest ecosystems in Nigeria are made up of the Nigerian lowland forests in the southwest, the Niger Delta swamp forests and the Central African mangrove forests around the south-central and southernmost parts, and the Cross-Niger transition forests, including the CrossSanaga-Bioko coastal forests in the southeast. The largest of these forest zones is the Nigerian lowland forests.
The Nigerian lowland forests is intricately linked to the millions of people living in the southwestern region of Nigeria, and is not any less significant to the rest of the world. In fact, a tripartite relationship has been observed between biodiversity, the indigenous people, and global climate. Poor rural communities depend on biodiversity and ecosystem services for health and nutrition, crop development, and as a safety net when faced with climate variability and natural disasters. ${ }^{1}$ Urban dwellers the world over depend on water provision and purification performed by forests and wetlands. Healthy forest ecosystems contain massive carbon reservoirs and are vital for regulating the global climate; ${ }^{1}$ hence, the role of biodiversity for man's survival cannot be overemphasized, but the question of conserving biodiversity is in no way straightforward. The area within the Nigerian lowland forest zone in southwestern Nigeria (see Figures 1 and 2) has been recognized as biologically important in containing significant species of plants and animals, and can be considered one of the most valuable areas in the country that secures water supply, maintains soil fertility, harbors rare/endangered species, and provides livelihoods for local people living within and around it, ${ }^{4-11}$ but at the same time the region also has some of the highest human population densities in tropical Africa, and throughout the area human numbers continue to grow rapidly. In this situation, establishing balance between human needs and the necessity of preserving biological resources is crucial, and all mechanisms put in place must ensure sustainability.

The objective of this paper is to examine the state of forest degradation and land use resulting from anthropogenic pressures. Drawing from data collected during various research efforts conducted from 2006 to 2012, information is evaluated based on important environmental and societal indicators. This paper attempts to review the accelerating rate of forest conversion and the series of management strategies undertaken to achieve conservation priorities alongside sustainable livelihood in this highly threatened ecoregion - the Nigerian lowland forests.

\section{The Nigerian lowland forests - a description}

The Nigerian lowland forests, located between geographic coordinates $05.20 \mathrm{~N} 08.15 \mathrm{E}$ and $05.79 \mathrm{~N}$ 05.34E, extend from the southwestern border of the country, overlapping the boundary shared by the Republic of Benin and Nigeria stretching eastwards to the western edge of the River Niger. The ecoregion is bordered by the River Niger to the northeast, a boundary it shares with the Cross-Niger transition forests, with the Niger Delta swamp forests situated southward 


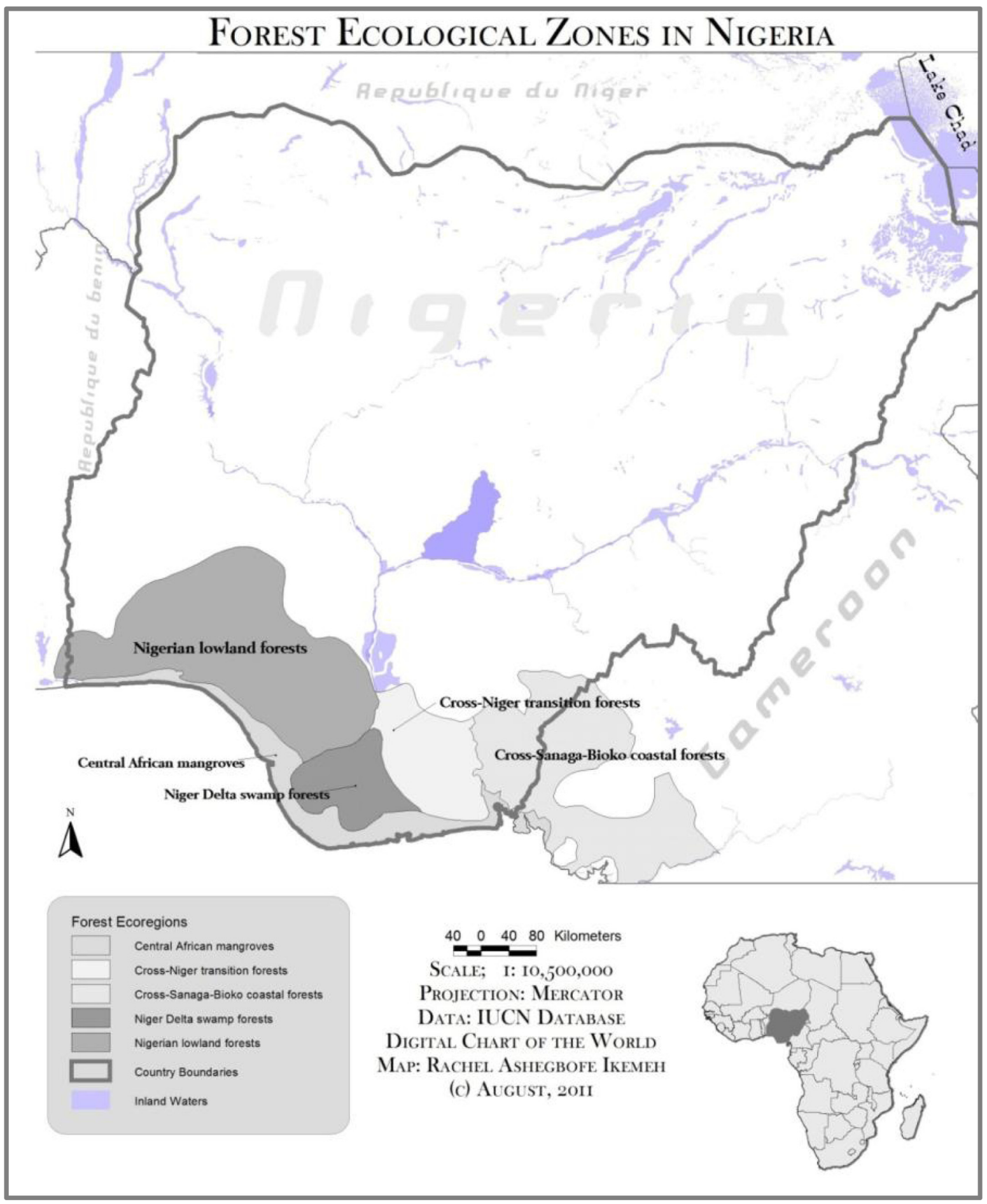

Figure I The rainforest ecoregions of southern Nigeria. The Nigerian lowland forests considered in this paper extend from the edge of the Republic of Benin to the delta. Abbreviation: IUCN, International Union for Conservation of Nature.

between the two ecoregions. To the south, the forests are separated from the coast by a strip of Central African mangroves and inland water. Northwards, the forests taper off into a mosaic of forest and savanna habitat (Guinean forest-savanna mosaic). The Nigerian lowland forests cover a land area of about $69,113 \mathrm{~km}^{2}$ covering approximately eight states in the country, encompassing much of Edo, Ondo, Ogun, Osun, and Ekiti states, including northern Lagos and Delta states, as well as southeast Oyo State.

Except for random inselbergs (slopes or hills of crystalline rocks rising abruptly from the plain), the region is generally low-lying, with undulating elevations averaging 


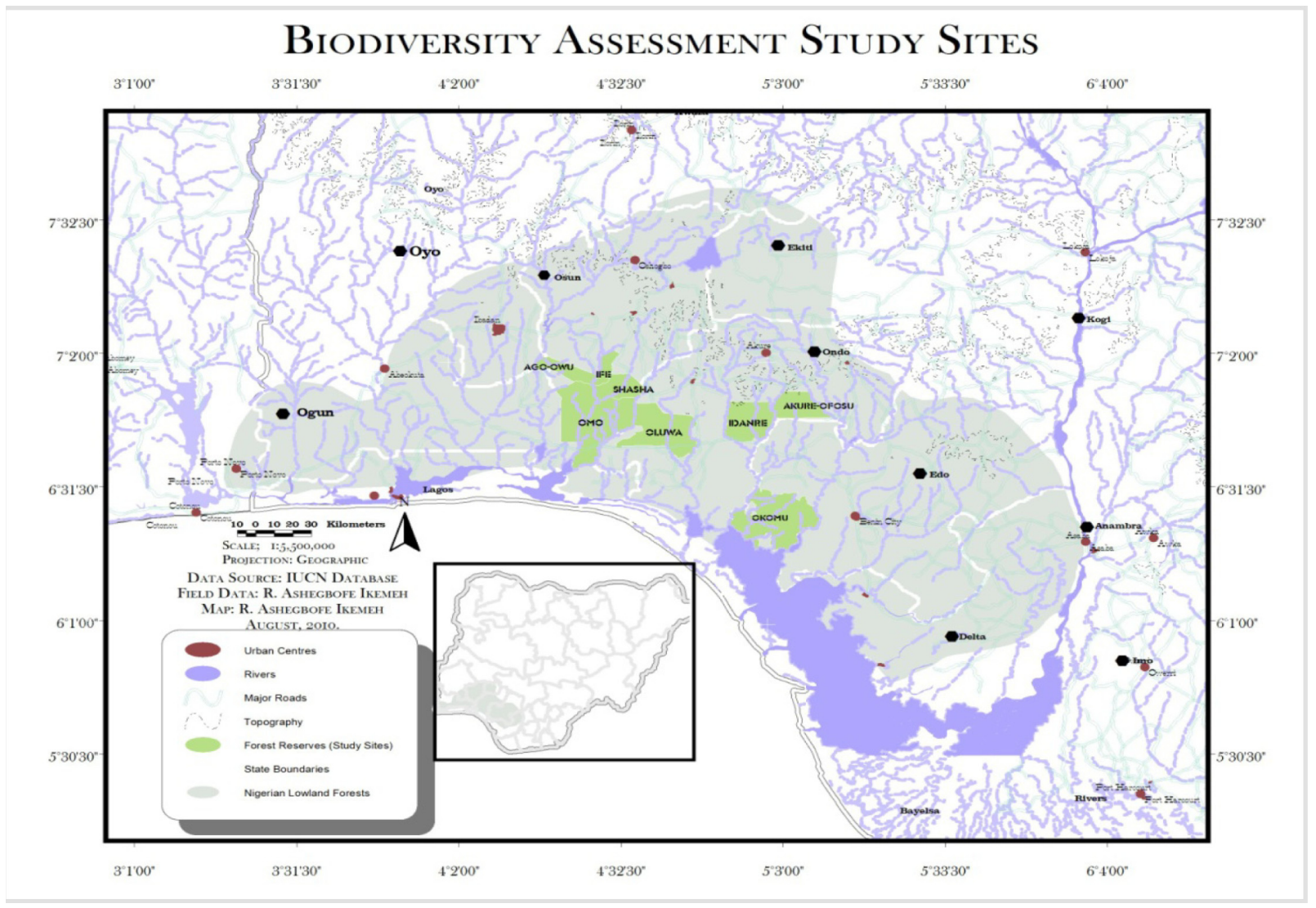

Figure $\mathbf{2}$ This map shows the area covered by the Nigerian lowland forests and survey sites. Abbreviation: IUCN, International Union for Conservation of Nature.

150 meters (m) above sea level and rarely exceeding $300 \mathrm{~m}$. Elevation gradually rises from the south, where altitude may be as low as $5 \mathrm{~m}$ above sea level, making most of the southernmost area of the region swampland. Geologically, the area lies on crystalline rocks of undifferentiated basement complex, which in the southern parts is overlain by Eocene deposits of sand, clay, and gravel. ${ }^{4}$ There is a gradual increase in altitude northward, broken up by the valleys of the major rivers and the several tributaries connected to them. The extensive network of large rivers that drain the ecoregion has several equally large tributaries. Some major rivers include the Ogun, Osun, Oni, and the Owena, as well as Osse, Omo, Shasha and Oluwa. None of these rivers flows directly into the sea, but they discharge into narrow lagoons that run along the entire coast from the Niger Delta to the Republic of Benin. ${ }^{6}$ Precipitation is generally typical for a tropical climate, characterized by distinct periods of wet (rainy) and dry seasons, with the latter lasting from December to February usually accompanied by harmattan, the dry northeast winds blowing from the Sahara. Little variations exists across the region in cumulative annual rainfall. In general, mean annual rainfall is between 1,500 and $2,500 \mathrm{~mm},{ }^{4,6}$ with peak periods between July and October. Temperatures in the region can reach $35^{\circ} \mathrm{C}$ and can drop to as low as $18^{\circ} \mathrm{C}-20^{\circ} \mathrm{C} .{ }^{9}$

The vegetation of the region is typical of the Congolese subdivision of the Guinea: the Congolese moist forest zone. It is a natural mixed moist semideciduous rainforest. This can be distinguished into a dry evergreen mixed deciduous forest in the northern part and a wet evergreen forest in the southern part. ${ }^{12}$ In the drier northern portion of this ecoregion, dominant trees belong generally to the Sterculiaceae family (Cola spp., Mansonia altissima, Nesogordonia papaverifera, Pterygota spp., Sterculia spp., Triplochiton scleroxylon), the Moraceae family (Antiaris africana, Ficus spp., Milicia excelsa), and the Ulmaceae family (Celtis spp., Holoptelea grandis). ${ }^{6}$ In the moister southern parts of the ecoregion, the forest is dominated by members of the Leguminosae family (Brachystegia spp., Cylicodiscus gabunensis, Gossweilerodendron balsamiferum, Piptadeniastrum africanum). ${ }^{6}$

\section{The human dimension}

According to the UN, it is projected that the human population of Nigeria will increase significantly to about 800 million 
people before the close of the twenty-first century, while the US Census Bureau projects that Nigeria could be the fourth most populous country in the world by 2050 . In addition, Nigeria is composed of more than 250 ethnic groups; therefore political, administration will remain crucial to the development of all sectors and for ensuring sustainability. Presently, there are eight states between the southwestern border and the River Niger that have some parts or in some cases the whole of their territory within the Nigerian lowland forest zone: Oyo, Ogun, Lagos, Osun, Ekiti, Ondo, Edo, and Delta. Several of these states now have very little forest cover left, though significant forest areas can still be found in Ogun, Ondo, Osun, Ekiti, and Edo.

Demographic data for Nigeria suggest that about 55 million people live within the southwestern region, which is about a quarter of the country's population, although the widely criticized 2006 census put the population for the eight states at $31,457,691 .{ }^{13}$ The land area is relatively small, especially compared to the northern parts of the country; therefore, the region is densely populated, with an average of 100-500 people per square kilometer. However, most of the population is concentrated in major urban areas across the region, especially Lagos, Ibadan, Benin City, Akure, and Warri, although there are still significant numbers of people spread across the suburban and rural areas (see Figure 3).

For most of human history, the forests of southwestern Nigeria have been occupied by man. ${ }^{14}$ The dense rainforest and the thriving economy kept populations small and scattered, with only a small number of indigenous ethnic populations utilizing the area's forest resources for social and economic purposes. Nonetheless, in the past half-century this has all changed. There have been steady influxes of migrants from every corner of the country, resulting in the number of people living within and around the forest reserves of southwestern Nigeria now being in the hundreds of thousands. Over the last 30 years, the human population has proliferated and created tremendous demands for jobs. Initially, the exotic tree plantations

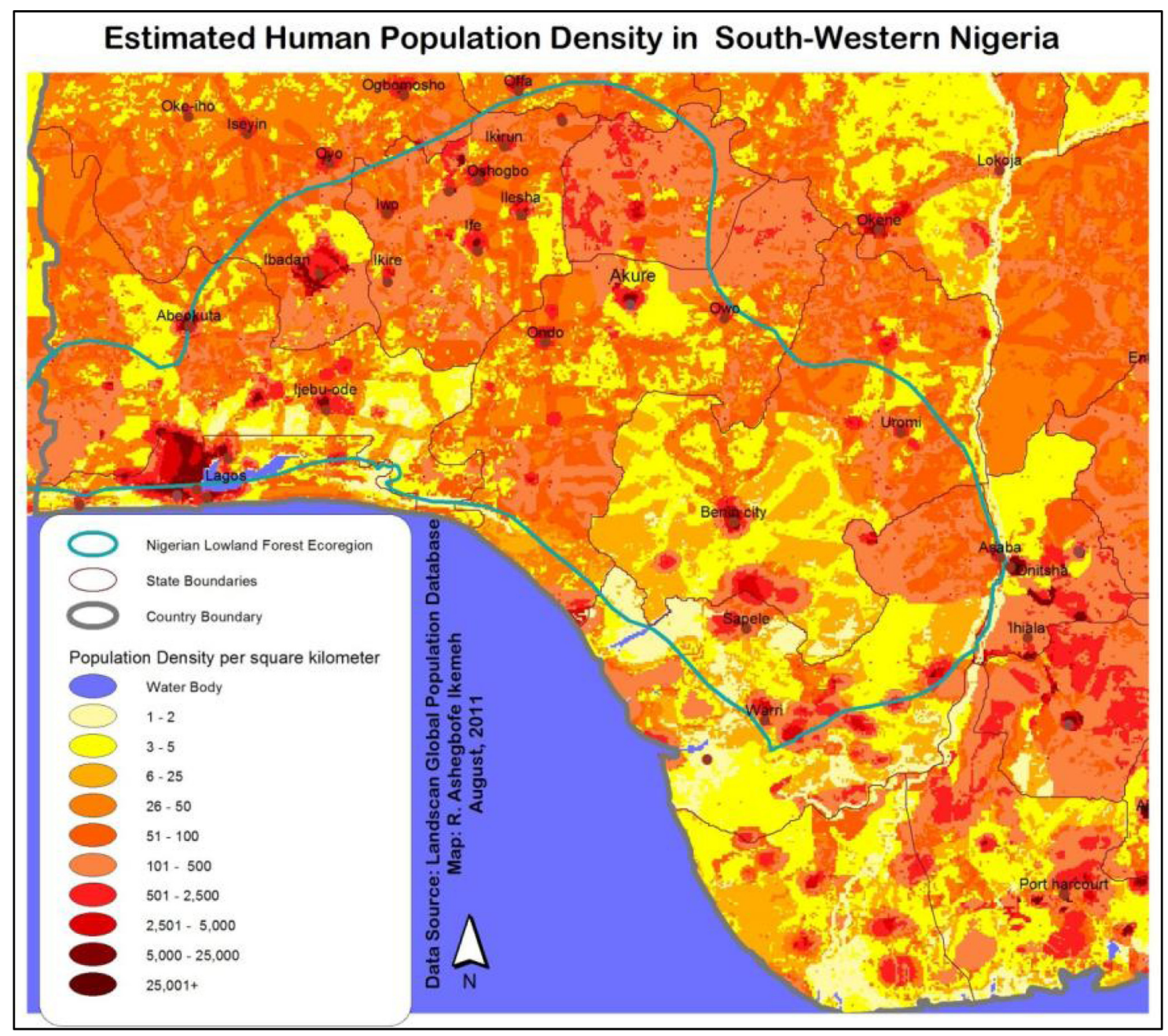

Figure 3 Human population density in southwestern Nigeria. 
formed a major part of the economic growth agenda from the late 1960 s to the early 1990s, and including the logging industries provided employment for huge numbers, but when this collapsed in the mid-1990s due to the worsening economic situation in the country, work opportunities dried up for most of the local population, and many turned to farming as the next alternative. Despite these developments, hundreds of new arrivals continued to show up in the area on a regular basis. About $70 \%$ of locals encountered during surveys conducted in some forest reserves in the region referred to themselves as "strangers." ${ }^{11}$ With $47 \%$ of the country's populace between the ages of 20 and 40 years, it is expected that more people will migrate to these areas in search of some means of livelihood.

\section{Assessing biodiversity patterns and conservation priorities}

Based on research conducted between 2006 and 2012 under various conservation research/high conservation-value assessment projects, several survey approaches were employed in gathering data and understanding the ecological and sociological aspects of the region. Field surveys were carried out in ten forest reserves: Okomu and Ohosu forest reserves in Edo State; Omo forest reserve in Ogun State; Oluwa, Idanre, Akure-Ofosu and Ala forest reserves in Ondo State; and Shasha, Ife, and Ago-Owu forest reserves in Osun State; Ise forest reserve in Ekiti State. Cumulatively, these survey areas covered $5,654.7 \mathrm{~km}^{2}$, which is about $8 \%$ of the total land surface covered by the Nigerian lowland forests and almost half the land area of designated forest reserves in the ecoregion.

Although varied survey methods were used in different sites depending on the underlying purpose for which the survey was initiated, the goals were nevertheless consistent in addressing gaps in existing knowledge, documenting the region's biological importance, mapping existing/new information on biogeographic patterns in the Nigerian lowland forests, and promoting knowledge and acceptance of the

Table I Summary of biodiversity assessment and findings in eight forest reserves

\begin{tabular}{|c|c|c|c|c|c|c|c|c|}
\hline $\begin{array}{l}\text { Area } \\
\text { (forest } \\
\text { reserves) }\end{array}$ & $\begin{array}{l}\text { Size } \\
\text { (ha) }\end{array}$ & $\begin{array}{l}\text { Survey } \\
\text { period }\end{array}$ & $\begin{array}{l}\text { Survey } \\
\text { method(s) }\end{array}$ & $\begin{array}{l}\text { Distance } \\
\text { surveyed } \\
\text { on foot }(\mathbf{k m})\end{array}$ & $\begin{array}{l}\% \text { of forest } \\
\text { loss** (as at } \\
2007 \text { ) }\end{array}$ & Land-use types & $\begin{array}{l}\text { Number of } \\
\text { RTEES* } \\
\text { (mammals) } \\
\text { still present }\end{array}$ & $\begin{array}{l}\text { Encounter rates } \\
\text { of mammals/km } \\
\text { (in remnant } \\
\text { forest) }\end{array}$ \\
\hline Ago-Owu & $240 \mathrm{~km}^{2}$ & 2008 & $\begin{array}{l}\text { Recce- } \\
\text { transect }\end{array}$ & 10 & 66.9 & $\begin{array}{l}\text { Farmlands, } \\
\text { tree plantation }\end{array}$ & 4 & Not determined ${ }^{\dagger}$ \\
\hline $\begin{array}{l}\text { Akure- } \\
\text { Ofosu }\end{array}$ & $\begin{array}{l}403.3 \mathrm{~km}^{2} \text {, } \\
\text { (Ext. } \\
\text { I } 98.05 \mathrm{~km}^{2} \\
\text { also known } \\
\text { as Ala) }\end{array}$ & $\begin{array}{l}2010 \\
2012\end{array}$ & Recce & $\begin{array}{l}\text { I } 86(2012 \\
\text { survey) }\end{array}$ & $\begin{array}{l}26.942 \% \text { as } \\
\text { at } 2013\end{array}$ & $\begin{array}{l}\text { Farmlands, illegal } \\
\text { cannabis plantation }\end{array}$ & 6 & $\begin{array}{l}\text { Not determined }{ }^{\dagger} \\
(2010) ; 2.0 \mathrm{I} / \mathrm{km} \\
(2012)\end{array}$ \\
\hline Idanre & $574 \mathrm{~km}^{2}$ & $\begin{array}{l}2009 \\
2012\end{array}$ & $\begin{array}{l}\text { Recce- } \\
\text { transect }\end{array}$ & 240.87 & $\begin{array}{l}39.9(69 \% \text { as } \\
\text { at } 2013)\end{array}$ & $\begin{array}{l}\text { Farmlands, } \\
\text { tree plantation }\end{array}$ & 6 & $\begin{array}{l}\text { I.I2 (2009); } \\
0.49 \text { (20I2) }\end{array}$ \\
\hline Ife & $142 \mathrm{~km}^{2}$ & 2008 & Recce & 20 & 46.8 & $\begin{array}{l}\text { Farmlands, } \\
\text { tree plantation }\end{array}$ & 3 & Not determined ${ }^{\dagger}$ \\
\hline Okomu & $\mathrm{I}, 082 \mathrm{~km}^{2}$ & $\begin{array}{l}2007 \\
2009\end{array}$ & $\begin{array}{l}\text { Recce, } \\
\text { recce-transect }\end{array}$ & $\sim 150$ & $\begin{array}{l}80.6\left(212 \mathrm{~km}^{2}\right. \\
\text { of forests is } \\
\text { protected } \\
\text { within the } \\
\text { National Park })\end{array}$ & $\begin{array}{l}\text { Farmland, settlements, } \\
\text { oil palm plantation, } \\
\text { rubber plantation, } \\
\text { national park }\left(212 \mathrm{~km}^{2}\right)\end{array}$ & 8 & $\begin{array}{l}0.36 \text { (outside the } \\
\text { national park) }\end{array}$ \\
\hline Oluwa & $827 \mathrm{~km}^{2}$ & 2008 & $\begin{array}{l}\text { Recce- } \\
\text { transect }\end{array}$ & 50 & 57.9 & $\begin{array}{l}\text { Tree plantation, } \\
\text { farmlands, settlements }\end{array}$ & 5 & 0.94 \\
\hline Omo & $\mathrm{I}, 324.7 \mathrm{~km}^{2}$ & $\begin{array}{l}2007 \\
2008 \\
2009\end{array}$ & $\begin{array}{l}\text { Recce- } \\
\text { transect }\end{array}$ & $\sim 300$ & 71.2 & $\begin{array}{l}\text { Tree plantation, } \\
\text { farmlands, } \\
\text { settlements }\end{array}$ & 6 & 2.33 \\
\hline Shasha & $309 \mathrm{~km}^{2}$ & 2008 & $\begin{array}{l}\text { Recce- } \\
\text { transect }\end{array}$ & 30 & 22.2 & $\begin{array}{l}\text { Farmlands, } \\
\text { tree plantation }\end{array}$ & 5 & 0.33 \\
\hline Ise & $46.6 \mathrm{~km}^{2}$ & 2012 & Recce-transect & $120.6 \mathrm{~km}$ & $\begin{array}{l}31.553 .3 \% \text { as } \\
\text { at } 2013\end{array}$ & $\begin{array}{l}\text { Farmlands, Illegal } \\
\text { cannabis plantation }\end{array}$ & & 0.28 \\
\hline Ohosu & $508.03 \mathrm{~km}^{2}$ & 2012 & Recce & $12 \mathrm{~km}$ & 67.9 & Farmlands & 4 & Not determined \\
\hline
\end{tabular}

Notes: *Mammals in this category (with IUCN Red List ranking) include forest elephant (Loxodonta africana cyclotis) - NT, Nigeria-Cameroon chimpanzee (Pan troglodytes ellioti) - EN, red-capped managbey (Cercocebus torquatus) - VU, Maxwell's duiker (Philantomba maxwelli) - TR, Nigerian white-throated guenon (Cercopithecus erythrogaster) VU, common leopard (Panthera pardus) - NT, African golden cat (Caracal aurata) - NT, and tree pangolin (Manis tricuspis) - NT; †areas surveyed where encounter rates per kilometer could not be determined due to unsystematic approach used to survey these areas. ** \% Of forest loss is calculated from GIS analysis on satellite imagery. Abbreviations: RTEES, rare, threatened, endangered and endemic species; IUCN, International Union for Conservation of Nature; NT, near threatened; TR, threatened; EN, endangered; VU, vulnerable; Ext. Extension (Akure-Ofosu Extension also known as Ala forest reserve). 


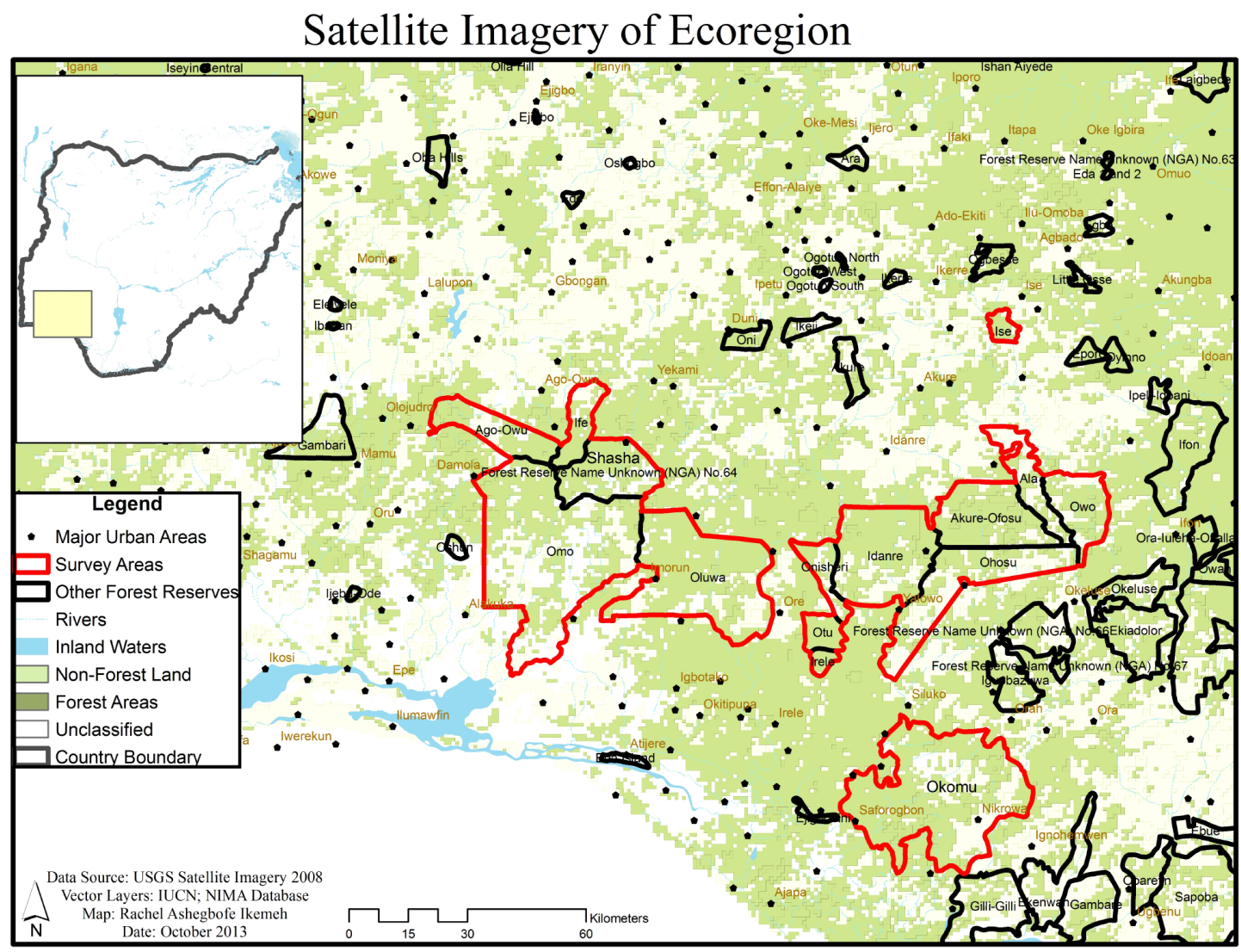

Figure 4 Satellite imagery of the Nigerian lowland forests. Areas in darker-shaded green can be considered natural forests and other tree cover types (plantations and mature farmlands); lighter-shaded green are other land cover types such as barelands, settlements, new clearings etc.

forests' biodiversity and conservation needs. In addition, field assessments involved trekking into the forests following predetermined systematic survey routes to explore a wider range of the study area; these trips lasted an average of 20 days, during which approximately $500 \mathrm{~km}$ was surveyed on foot. More typically, line transects and reconnaissance surveys were applied to several kilometers along predetermined survey routes, noting details on vegetation type/status, animal/plant presence, and evidence of human activities (see Table 1).

Data were also collected from published literature and existing databases. Resources such as geographic information systems and distributional data were explored, including the application of remote-sensing methods to examine forest cover. Specifically, Landsat and ASTER (Advanced Spaceborne Thermal Emission and Reflection Radiometer) satellite imagery were used to assess the rate of change in forest cover in the study areas. Discussions/interviews were also held with resource users (local residents and nonresidents) and desk and field forestry officials, including government forest department officials. These discussions provided vital information on the forest reserves within the historical, administrative, and social contexts.

\section{A review of forest-management practices in southwestern Nigeria}

The earliest form of forest management began in Nigeria in 1897, with the creation of a Department of Woods and Forests for the Colony and Protectorate of Lagos ${ }^{15}$ to regulate timber extraction that began as early as 1880 s. The British colonial government established forest reserves in order to further check the utilization of forest resources. Reserves were created through enacted forestry ordinances,${ }^{16}$ where rights were given to local communities to hunt, fish, harvest nontimber forest products (NTFPs), tap rubber, and farm within predefined areas. ${ }^{14}$ Forest reservation throughout the country was virtually completed before 1930 , although in the Niger Delta and in the savanna region, additional reserves were created as late as the $1960 \mathrm{~s}$ and $1970 \mathrm{~s},{ }^{15}$ so that the total area covered by designated forest reserves in Nigeria is $96,000 \mathrm{~km}^{2}$ consisting of $20,700 \mathrm{~km}^{2}$ reserved land in the forest ecological zone in which case 82 reserves were created within the Nigerian lowland forests covering $10,504 \mathrm{~km}^{2}-$ about $15 \%$ of the land area covered by the ecoregion. Even during this period, large tracts of forest still fell outside the forest reserves. Prior to 1960, forest reserves were managed 
under working plans, and the colonial administrators ensured strict adherence to these plans.

However, timber extraction intensified by 1960, and following the onset of oil-windfall revenues in the 1970s, domestic demand for timber products increased dramatically. Economic trees such as the mahoganies and the iroko (Milicia excelsa) were selectively logged in large quantities under more relaxed forestry regulations that sought to boost foreign exchange and encourage indigenous businessmen (prior to this time, the industry had been dominated by expatriates/foreign companies). Nonetheless, the fact that tropical forests are exhaustible after continuous extractive activities was realized very early in the exploitation history, and to ensure constant supply of hardwood, the Nigerian forestry departments, like other African forestry authorities, tried to take up the challenge of silviculture in moist forests, beginning in the $1950 \mathrm{~s} .{ }^{4}$ This may have been developed from initial timber rules introduced as early as 1906, which demanded that loggers set up plantations or ensure the release of natural regeneration patches. ${ }^{15}$ Some of the methods relied on natural regeneration, while others on artificial regeneration.

By the 1940s, the Nigerian tropical shelterwood system, based on the Malayan experience, was adopted. It involved the natural regeneration of valuable tree species by climber cutting and opening up the canopy by way of poisoning trees considered less valuable. ${ }^{6,15}$ This system was later abandoned in 1966 when judged ineffective and not cost-effective. Thereafter, plantation forestry soon replaced the tropical shelterwood system. Although exotic tree plantations were first cultivated in eastern Nigeria in 1932 to provide pit prop at the Enugu coal mines ${ }^{6}$ cultivation was widespread in the southwestern

A

Historic Rate of Deforestation in Oluwa Forest Reserve (1972 - 2007)
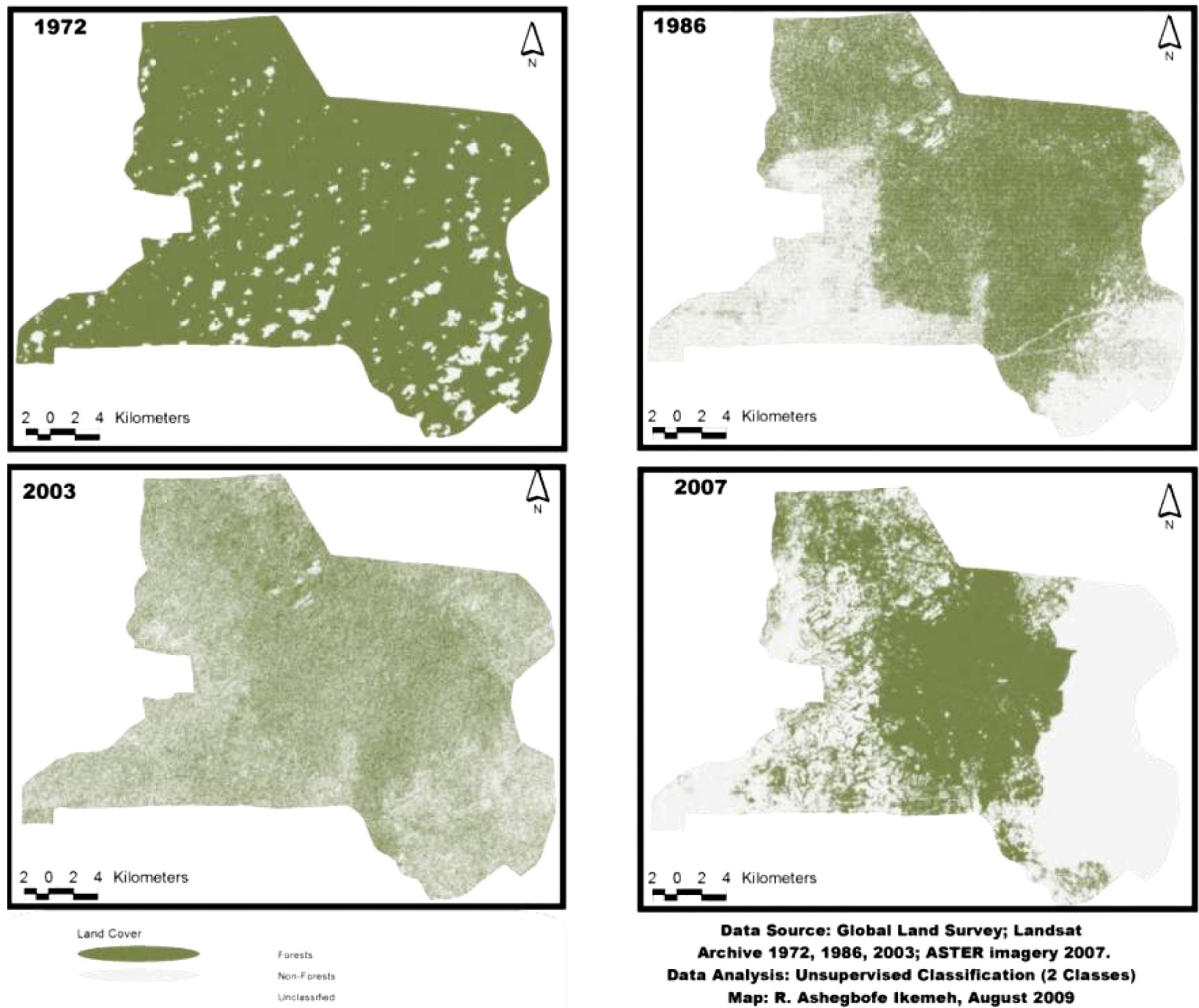

Data Source: Global Land Survey; Landsat Archive 1972, 1986, 2003; ASTER imagery 2007. Data Analysis: Unsupervised Classification (2 Classes) Map: R. Ashegbofe Ikemeh, August 2009 


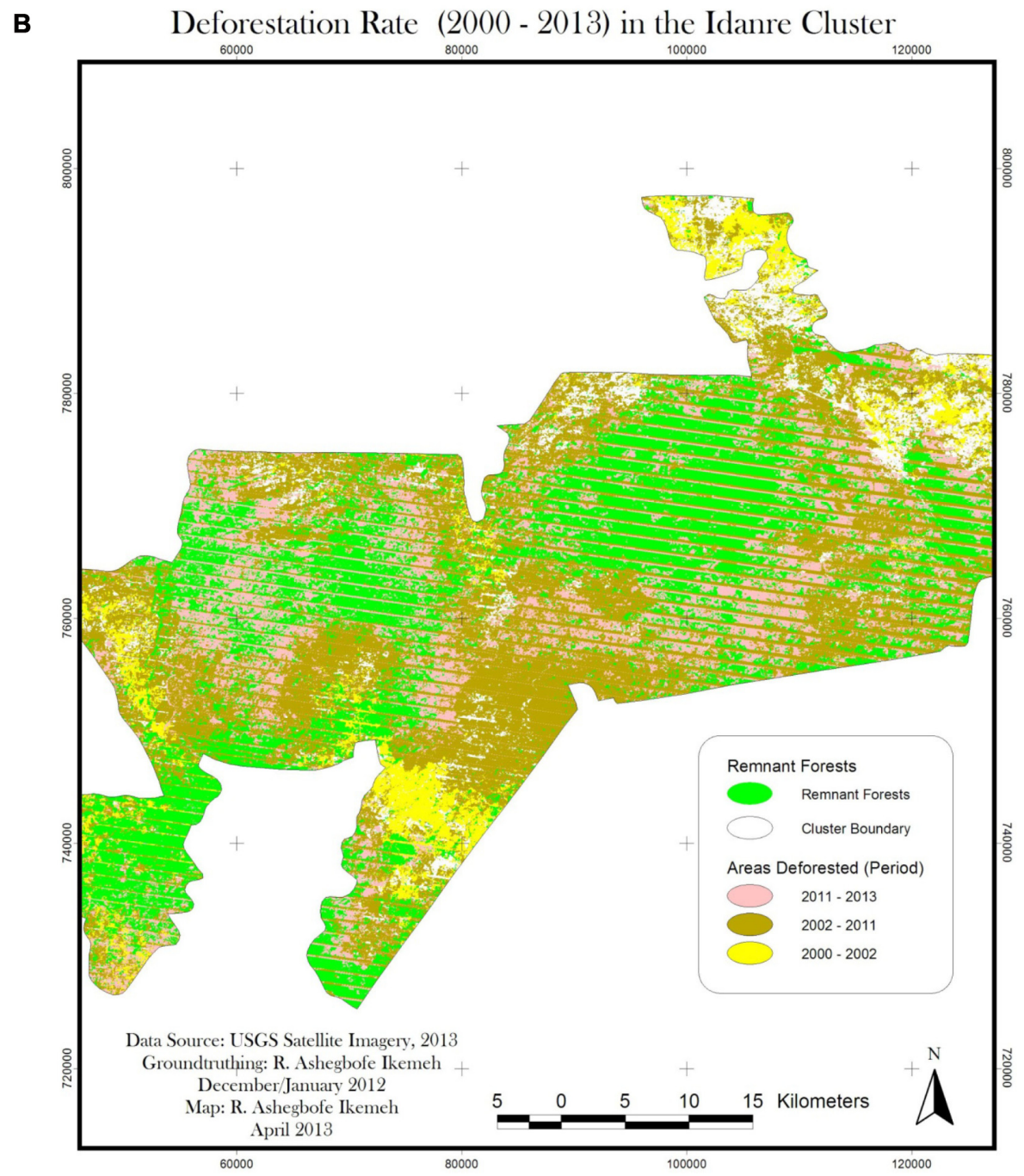

Figure 5 Deforestation and changes in Idanre Forest Cluster over time (2000-20I3).

region due to a number of reasons: exotic tree species cultivated are fast-growing, eg, Tectona grandis and Gmelina arborea, which are also important as pulpwood; the system attracted international funding from the World Bank and the African Development Bank for its inherent potential in facilitating economic growth; and also it seemed relatively easier to maintain because farmers were mandated to plant the tree species as a condition of growing food crops on forest land in an agroforestry method known as the taungya system, a structure embraced by the government since it seemed to appease the growing pressure from the people to utilize reserved land for farming. At the beginning of this practice, indigenous tree species such as Triplochiton scleroxylon, Nauclea diderrichii, Terminalia spp., and Khaya spp. were planted, but teak and Gmelina spp. were soon the most preferred for this practice. By the mid-1980s, systematic management of the Nigerian forest estates had declined to its lowest levels. The use of working plans had been abandoned, and resources were barely made available to control exploitation of the forest. ${ }^{15}$

\section{Observations on the extent of forest exploitation}

Findings and observations made during field surveys provide evidence that some forest reserves have been completely converted to farmlands or other land-cover types; there is hardly any significant forest vegetation remaining outside protected areas, except for small patches utilized as sacred groves or for other forms of religious purposes by some communities. Likewise, the remaining forest reserves containing significant forest cover have also come under immense pressure from human activities, so that most of the remaining forests are severely degraded, modified, and fragmented.

Logging, farming and hunting were identified (see Figure 4) as the three most critical activities carried out 


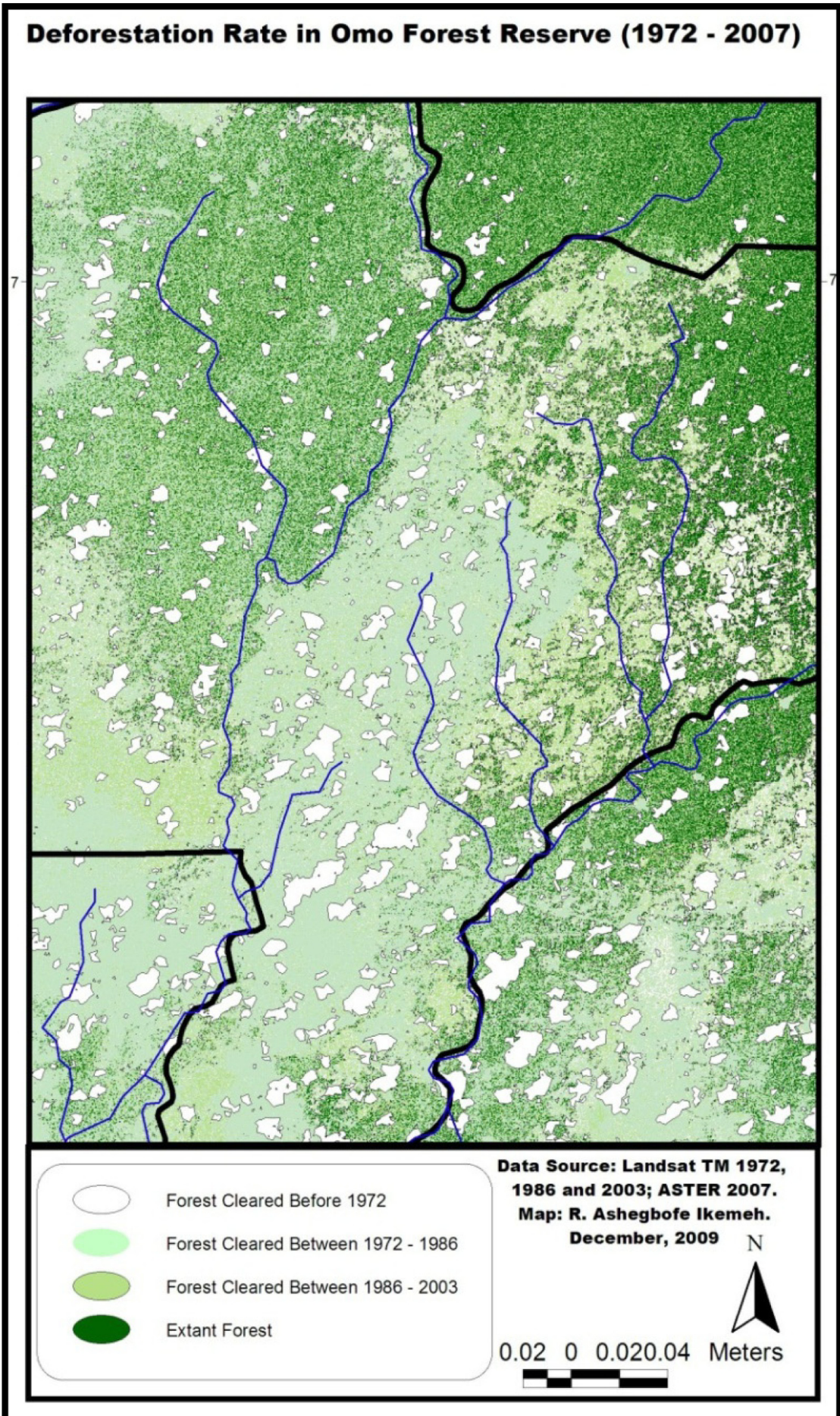

Figure 6 Deforestation in Omo Forest Reserve.

throughout the area. Other extractive forms of resource use, such as the collection of Thaumatococcus daniellii (broad leaf used for wrapping food), Irvingia gabonensis (edible seed), Garcinia mannii (chewing stick), and Carpolobia lutea (sanda stick), amongst others, also made up a substantial part of overall economic activities carried out in the region. ${ }^{17}$
However, farmlands are the most prevalent land-use types replacing forests in the region as more farmers encroach on forest lands to grow both food and cash crops for subsistence and commercial purposes. Besides these crops, large areas of forests cleared for cultivating Cannabis sativa, also known as Indian hemp, have been observed in some of the forest 
reserves, particularly in the Akure Ofosu Forest Reserve. For example, some results have revealed that farming accounts for $94.9 \%$ of land-use activity in a forest reserve. ${ }^{18}$ Studies suggest that since the late $1980 \mathrm{~s}$, farmers have continued to increase their activities in many of the reserves, converting much of the forest land to large extensive cocoa farms and for other types of food crops, mostly plantain. The result has been the rapid disappearance of forest cover. An average annual deforestation rate of $4.5 \%$ over a 16 -year period from 1986 to 2002 was reported in an area covering $955.9 \mathrm{~km}^{2}$ (comprising designated forest reserves and unprotected areas) within the Nigerian lowland forests. ${ }^{8}$ Similarly, industrial plantations were another major contributor to forest conversion. There were $216 \mathrm{~km}^{2}$ of industrial forest plantations in Nigeria as of $1990,{ }^{4}$ and forest loss in the Omo Forest Reserve was 36.8\% from 1972 to 1986 (Figure 6). Figure 5 shows the historic rate of deforestation in Oluwa Forest Reserve in Ondo State, where there is an observable change in forest land and nonforest land over a 35-year period. Similarly, Figure 5b depicts a more recent analysis of deforestation rate for the neighbouring Idanre forest cluster made up of 8 forest reserves including Idanre, Akure-Ofosu, Ala, Owo, Ohosu, Onisheri, Irele and Otu. Habitat assessments in the field and from satellite imageries indicate that only about $31 \%\left(669 \mathrm{~km}^{2}\right)$ of forests remain in the Idanre forest cluster much of which is within Akure-Ofosu and Idanre forest reserves. Public-domain USGS satellite data from 2000-2013 were used to assess the changes in land cover over during the 13 year period and to measure the rate of change in the Idanre forest cluster. This GIS analysis indicate that $744.5 \mathrm{~km}^{2}$ of forests was converted from 2000-2013 i.e. 34.5\% of the total land area. This further suggest that $4.5 \%\left(33.4 \mathrm{~km}^{2}\right)$ of forest is cleared each year within the Idanre forest cluster and $85.1 \%$ of forest conversion is driven by farming activities.

Excessive and uncontrolled timber extraction has also left the forests significantly degraded and depleted of several valuable tree species. At least 47 tree species found in the Nigerian lowland forests are economically important and considered commercially acceptable timber trees, ${ }^{4}$ some examples of which are Lophira alata, Terminalia ivorensis, Nauclea diderrichii, Khaya ivorensis, Milicia excelsa, Sterculia rhinopetala, Triplochiton scleroxylon, Afzelia bipindensis, Brachystegia nigerica, Chlorophora excelsa, and Terminalia superba. However, recent surveys observed that logs from the cotton tree Ceiba petandra, not previously regarded as "economic," are now heavily exploited due to the unavailability of other timber trees. ${ }^{10}$
An example from Omo Forest Reserve (Figure 6) provides another example of forest exploitation. In the second schedule of the order made under the ordinance that established the Omo Forest Reserve in 1941, rights were given to the communities to hunt, fish, harvest NTFPs, tap rubber, and farm within predefined areas specifically in the eastern part of the reserve within an area of about $4.4 \mathrm{~km}^{2}$ around the Oloji enclave. It also gave rights to the communal owners of the land to receive royalties from timber extraction. Nevertheless, timber extraction in the reserve dates back to the early 1900 s, even before the area was gazetted. In fact, 610 persons and five villages were recorded in 1916, when the reserve was first proposed by the then-conservator of forests, ${ }^{19}$ and about 37 villages and camps were counted around the lower Omo and Oni rivers. ${ }^{14}$ In 1966, plantations of Gmelina arborea began in the reserve (see Figure 7), and by the mid-1990s, a total area of 25,562 ha $\left(256 \mathrm{~km}^{2}\right)$ had been cultivated with the species. ${ }^{14}$ The project received support from the World Bank in the 1980s with the aim of supplying pulpwood to the Iwopin pulp and paper mill.

The excessive and uncontrolled timber extraction of the past three decades has left the forest depleted. This sentence repeats what was said two paragraphs ago. In general, very little emphasis has been placed on proper forest-harvesting methods, forest management, or rehabilitation. Additionally, farmers have exacerbated the condition of the forest. During the 1990s and 2000s, resident and migrant farmers increased considerably in the reserve, converting much of the forest land to large extensive cocoa farms, including plantain, cassava, and cocoyam. The result of this has been the rapid disappearance of forest cover, loss of biodiversity, soil degradation, and erosion. Other forms of resource use have also gone unchecked and have become unsustainable, especially the hunting of

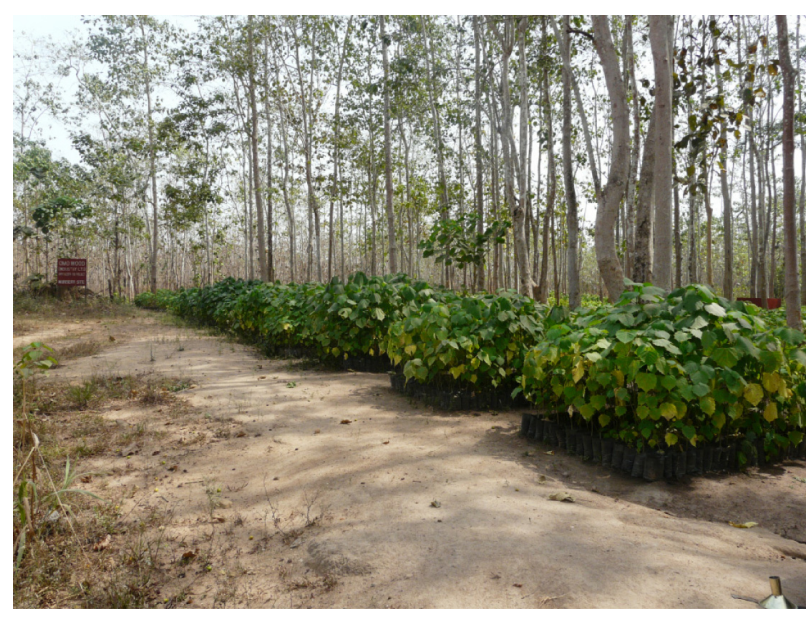

Figure 7 Gmelina plantation and nursery in Omo Forest Reserve. 


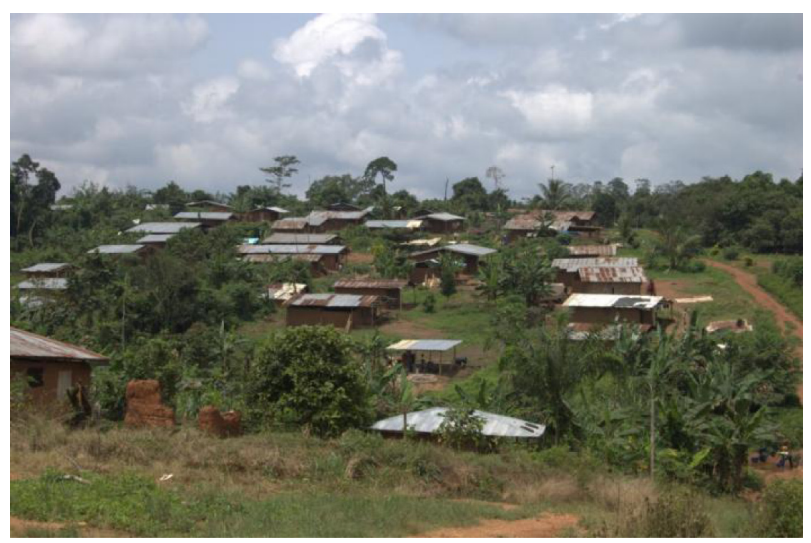

Figure 8 Settlements inside a reserve.

wildlife for bush meat, fishing by poisoning, and the harvest of NTFPs.

For these reasons, the forest is shrinking into smaller patches that become honeycombed with settlements, and connectivity gets eroded. An average annual deforestation rate of $4.5 \%$ over a 16 -year period from 1986 to 2002 was reported in an area covering $955.9 \mathrm{~km}^{2}$ in the southwest of Nigeria (see Figure 8). ${ }^{8}$ Investigation of the deforestation rate in the Omo Forest Reserve over a 35-year period from 1972 to 2007 revealed an average annual deforestation rate of $1.19 \%$, or $51.1 \mathrm{~km}^{2}$ every year (Figure 3). However, the deforestation rate between 1972 and 1986 was $36.8 \%$, due to the establishment of the Gmelina plantation.

Consumption and trade of bush meat is also a significant way people are using the forest resources. Although no quantitative data have been obtained for bush-meat trading or consumption, mammals and large birds make up a large proportion of animals, and those being hunted especially

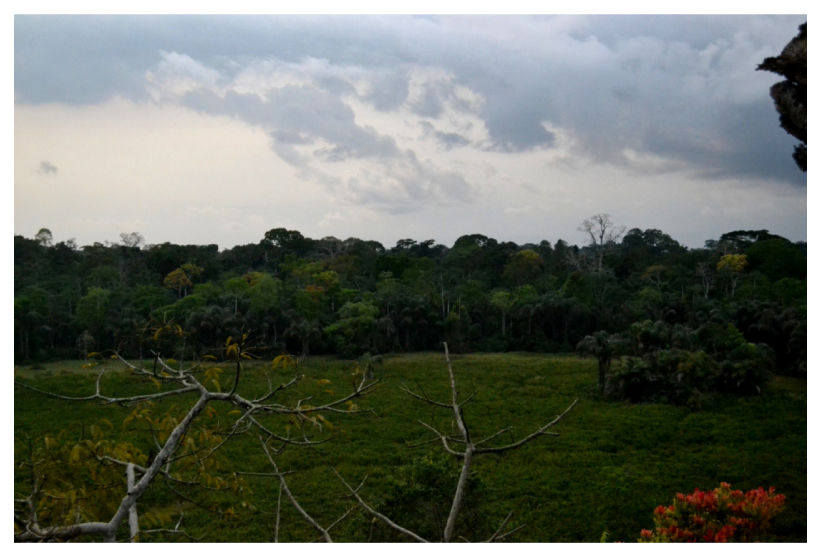

Figure $9 \mathrm{~A}$ view of the Okomu National Park, the only International Union for Conservation of Nature category II protected area in the Nigerian lowland forests, shows the value in biodiversity conservation-focused management method.
Table 2 Trade/Market Prices of Wildlife Species*

\begin{tabular}{|c|c|c|c|}
\hline Species & $\begin{array}{l}\text { Amount } \\
\text { (NGN) }\end{array}$ & $\begin{array}{l}\text { Amount } \\
\text { (USD \$) }\end{array}$ & Remarks \\
\hline $\begin{array}{l}\text { Chimpanzee } \\
\text { (Body parts) }\end{array}$ & 70,000 & 445.9 & $\begin{array}{l}\text { Price varies slightly as young adult } \\
\text { males fetch higher prices than } \\
\text { old/gray haired individuals. This } \\
\text { is probably due to the reports } \\
\text { that chimpanzees bones/parts are } \\
\text { mostly used to make protective } \\
\text { and strength charms (rituals) }\end{array}$ \\
\hline Buffalo & 60,000 & 382.2 & - \\
\hline Elephant (tusks & $\begin{array}{l}200,000- \\
, 500,000\end{array}$ & $\begin{array}{l}\text { I273.9- } \\
9554.1\end{array}$ & $\begin{array}{l}\text { Meat is rarely sold (hunters } \\
\text { admits sale to Hausa merchants } \\
\text { at this cost). Price varies greatly } \\
\text { depending on negotiations. }\end{array}$ \\
\hline Bush Pig & 40,000 & 254.8 & - \\
\hline Duiker & 4000 & 25.5 & $\begin{array}{l}\text { Some smaller ones cost as little } \\
\text { as USD20 }\end{array}$ \\
\hline Bushbuck & 10,000 & 63.7 & $\begin{array}{l}\text { Some large males can fetch } \\
\text { USD } 93.8\end{array}$ \\
\hline $\begin{array}{l}\text { Monkeys } \\
\text { (Small—Large) }\end{array}$ & $\begin{array}{l}1,200 \\
3,500\end{array}$ & $7.6-22.3$ & $\begin{array}{l}\text { Large monkeys usually consist of } \\
\text { red-capped mangabey and Alpha } \\
\text { males of Cercopithecus ssp }\end{array}$ \\
\hline $\begin{array}{l}\text { Grey Parrot } \\
\text { (tail feathers) }\end{array}$ & 10,000 & 63.7 & $\begin{array}{l}\text { Tail feathers used by native } \\
\text { doctors }\end{array}$ \\
\hline Grasscutter & $\begin{array}{l}3,500 \\
5,000\end{array}$ & $22.3-31.8$ & Depending on size \\
\hline Rock hyrax & $\begin{array}{l}1,800- \\
2,000\end{array}$ & $11.5-12.7$ & Depending on size \\
\hline
\end{tabular}

Notes: *The information presented in this table were collected during research conducted on Nigerian-Cameroon chimpanzee in the Idanre forest cluster and Ise forest reserve in $20012 / 2013$. (C) Ikemeh, R. A. (2013). Status Survey to determine the population viability of the Nigerian-Cameroon Chimpanzee in the Nigerian Lowland Rainforests of SW Nigeria: Ise forest reserve and the Idanre forest cluster. A report to the Ondo and Ekiti State Governments, SW/Niger Delta Forest Project, Nigeria. 60pp. ${ }^{20}$

are the mona monkey (Cercopithecus mona), Nigerian white-throated monkey (Cercopithecus erythrogaster), putty-nosed monkey (Cercopithecus nictitans), red-capped mangabey (Cercocebus torquatus), and Maxwell's duiker (Philantomba maxwellii). Others are the brush-tailed porcupine (Atherurus africanus) and red river hog (Potamochoerus porcus). Other wildlife not considered as bushmeat especially chimpanzees (Pan troglodytes ellioti) and forest elephants (Loxodonta africana cyclotis) are also frequently hunted. The former is favoured for traditional (ritual) medicines while the latter for its tusk. For instance, in 2012 alone there were 3 independent reports of elephant killings within the Idanre forest cluster and 1 report of elephant poaching in Omo forest reserve. Table 2 shows the economic value attached to some important wildlife species.

Although quantitative data were collected from observations of hunting activities (eg, gunshots heard, spent shotgun cartridges, snares, and animal carcasses), the overall impact of hunting activities in the area was deduced from the frequency of observation and the corresponding low numbers 
of animals observed in the forest. Hunting has undoubtedly driven most wildlife populations in the region to very small numbers that have become extremely wary of human presence. Even though traditional use of rudimentary hunting methods such as wire-snare traps and powder-guns is still widely practiced, hunting is by all means unsustainable in these forests. The number of hunters using the forests far exceeds the productive capacity of the wild animals, irrespective of the species. At most of the sites surveyed, it is unclear how much hunting is devoted to providing meat for local consumption and how much is driven by trade. However, interviews with hunters suggest that three-quarters of bush-meat harvest ends up in the local market, and in most successful outings where large animals such as buffalo or where significant numbers of relatively smaller animals have been hunted, trade is transacted in the nearest urban market. The species mostly found to be affected by hunting in the region are primates, as being the most vocal of all the animals in the region due to their social behavior, they draw unsolicited attention from hunters. Primates represented $>60 \%$ of the wildlife carcasses seen with hunters or close to human settlements in the region. In general, mammalian species within this region are perilously affected by current and future demand for bush meat.

\section{Conclusion and recommendations}

The biodiversity richness of the Nigerian lowland rainforests is only beginning to be understood. Though the ecoregion is relatively small and the rate of endemism is quite low, it contains five endemic animal species, including the near-endemic white-throated guenon (Cercopithecus erythrogaster, threatened) and Ibadan malimbe (Malimbus ibadanensis, endangered) occurring in the northernmost forest fringes of the ecoregion (in the parkland zone) and only observed in the Ibadan area, ${ }^{6}$ and at least two globally near-threatened species - the grey parrot (Psittacus erithacus) and yellow-casqued hornbill (Ceratogymna elata) - are found in the region. Other endangered species of high conservation value are the threatened African forest elephant (Loxodonta africana cyclotis), the nearthreatened common leopard (Panthera pardus), which is probably extinct in most parts of the ecoregion and was only confirmed present in Okomu National Park (Figure 9), and the near-threatened African golden cat (Caracal aurata). ${ }^{21}$ There is also the endangered Nigeria-Cameroon chimpanzee (Pan troglodytes ellioti); existing evidence suggests that there may be significant differences between populations in western and eastern Nigeria, ${ }^{22}$ and if this split is substantiated then the subspecies of chimpanzee found in this ecoregion will be considered critically endangered. ${ }^{6}$ Although the ecoregion contains few strictly endemic plant species, some of the plant assemblages contain both Upper and Lower Guinea plants, which are believed to be unique. ${ }^{6}$ Furthermore, there are over 200 species of large conspicuous trees, many of which are of economic value, including Nauclea diderrichii, Khaya ivorensis, Milicia excelsa, Cylicodiscus gabunensis, Brachystegia eurycoma, and Terminalia superba, amongst others, which are becoming increasingly rare.

The growing influx of people into the remaining protected areas and excessive economic activities put increasing pressure on the available forest resources. The process of land conversion seems to be escalating at a faster rate than previously thought, as the major preoccupations of the people are farming and indiscriminate logging. Rapid changes in forest cover and/or total conversion of the forest to other land-cover types seems inevitable in the short term, as large forest areas are currently being cleared and replaced with agricultural lands. ${ }^{23}$

Forests serve diverse ecological and economic purposes, but their capacity to provide these functions sustainably is jeopardized by existing unsustainable use. It is often widely suggested that biodiversity loss and poverty are interwoven problems, and that solutions must be tackled together. However, successes with integrated strategies are elusive: outcomes are either lopsided or are not easily recognizable. ${ }^{24}$

There is a sharp debate about the social impacts of conservation programs on rural populations and the perceived success of community-based approaches to conservation. One viewpoint of the argument claims "conservation" is contrary to the perceived interests of the poorest among local people, abolishing their land ownership and depriving them of their livelihood, while on the other hand, economic projects at the expense of biodiversity represent a loss of essential "insurance" and risk-management strategy, particularly in terms of the ability to switch to alternatives in the face of changing conditions, climate change, natural disasters, harvest failure, etc. ${ }^{24}$ Undoubtedly, the major ecological problems of deforestation and forest degradation discussed here have been associated with human population growth and socioeconomic trends. In the Nigerian lowland forest ecoregion, biodiversity conservation and local livelihood from the historical perspective and current trends have created a clash of interests. In the early 1900s, when most of the forest reserves in southwestern Nigeria were established by the British colonial administrators, they found that many 
of these forests were already inhabited by some indigenous tribes, although populations were low and scattered at the time. ${ }^{6,14}$ Consequently, laws made provisions for sustainable utilization of the forest resources by communal owners of the land with remittance of some percentage of profits from timber extraction. ${ }^{25}$ This may have seemed a workable integrative approach at the time, especially as population, poverty, and development needs did not become a major issue until the 1990s. However, when these issues surfaced, it appears conservation took a backseat. As an example, in Omo Forest Reserve in Ogun State, a total area of $25.6 \mathrm{~km}^{2}$ was converted to plantation by the mid-1990s, ${ }^{14}$ and this contributed to about $37 \%$ of total loss of forest cover in the reserve. Thus, it can be assumed that the deplorable state of the forests has been caused by inappropriate land-use practices driven by poor management initiative, rather than by extreme poverty, as is commonly presumed. Nevertheless, in the light of the foregoing, this could be an indicator for stakeholders to reevaluate the relationship that exists between local livelihood and biodiversity. More importantly, there must be a clear understanding of the dynamics that exist in this relationship to reflect modern challenges in order to set new priorities.

Beyond the obvious deforestation and degradation that was brought about by both illegal activities (such as cultivation of Indian hemp (Cannabis Sativa) plantations plus many farm encroachment were not approved by the forest managers) and forest-management practices that attempted to integrate the economic, social, and environmental constituents of forestry, as described by the Food and Agriculture Organization, ${ }^{19}$ there are more grievous consequences of forest loss. Several studies have found a significant reduction (approximately 90\%) in biological diversity of plants, mammals, birds, and reptiles in biological diversity following forest conversion to other land use. ${ }^{26}$ Furthermore, many animals that would ordinarily adapt to the change in their habitat become crop pests, putting them at risk of defensive poaching, if they are not first hunted for their meat source, thereby accelerating species extinction. Similarly, the destruction of natural habitats increases the risk of flooding. Despite these consequences of deforestation, none is yet as threatening as climate change. When we clear-cut forests, as has occurred at a catastrophic rate in the Nigerian lowland forests and in many other tropical forest landscapes, the trees are not available to absorb excess carbon dioxide from the atmosphere and convert it to biomass; therefore, there needs to be a critical evaluation of the relationship that exists between the growth of human enterprises with the goods and services provided by forest resources and preserving these resources for future posterity.

Without a doubt, with Nigeria's huge human population and going by Human Development Index reports, the country has some of the poorest people in the world, making the question of conservation and use of forests rather complicated, coupled with a history of political instability, corruption, and religious/socioeconomic woes. Nevertheless, as regards biodiversity conservation and local livelihoods in a human-dominated landscape, such as in the case described here, each is critical and achievable, but only if they are tackled with the right perspective and utmost integrity. Much therefore depends on how conservation projects are designed and implemented, rather than on the relative merits of biodiversity as a mechanism for poverty reduction. ${ }^{24}$ In any case, overlooking the controversies and the development of cautionary steps on such significant matters is a gamble far too risky to be settled by logic and concepts perceived on the international scene. Evidently, to get effective strategies in place to resolve biodiversity loss and ensure local sustenance in a human-dominated landscape, what is imperative in order of priorities is: good governance, with leaders at all levels guided by service and integrity; sound and comprehensive research efforts, paramount for making informed decisions; participatory decision-making processes, allowing indigenous people to participate in the matters that concern their source of livelihood; having clear objectives and realistic expectations, with strategic projects targeted at addressing specific issues; a flexible policy framework, with recognizable and definite policies that encompasses the short-term and long-term necessities within specified timeframes; and tactful implementation and periodic evaluation that should involve institutional development and capacity-building.

\section{Acknowledgments}

This paper was prepared with information gathered from research carried out in ten forest reserves: Okomu Forest Reserve (2006/2007 and 2009), Omo Forest Reserve (2007, 2008, and 2009), Oluwa Forest Reserve (2008), Shasha, AgoOwu, and Ife forest reserves (2008), Idanre Forest Reserve (2009, 2012), Ise Forest Reserve (2012) and Akure-Ofosu Forest Reserve (2010, 2012), under the auspices of the Leventis Foundation, Nigerian Conservation Foundation (NCF), Permian UK, Environmental Resource Management (ERM), Rufford Small Grants Foundation (RSGF), SW/Niger Delta Forest Project and the African Wildlife Foundation. These organizations/companies provided financial support and/or stimulus for surveys. The author is also grateful to various 
state governments, professionals, and colleagues including local assistants who were instrumental in the study design, data collection, and survey output.

\section{Disclosure}

The author reports no conflicts of interest in this work.

\section{References}

1. Secretariat of the Convention on Biological Diversity. Sustainable Forest Management, Biodiversity and Livelihoods: A Good Practice Guide. Montreal: SCBD; 2009.

2. United States Census Bureau. International programs - International Data Base. Available from: http://www.census.gov/population/ international/data/idb/informationGateway.php. Accessed August 11, 2013.

3. United Nations. World Population Prospects: The 2010 Revision. New York: UN; 2011

4. Isichei AO. Omo Biosphere Reserve, Current Status, Utilization of Biological Resources and Sustainable Management (Nigeria). Paris: UNESCO; 1995

5. Ola-Adams BA. Biodiversity Inventory of Omo Biosphere Reserve, Nigeria. Ibadan, Nigeria: Nigerian National Man and the Biosphere Committee; 1999.

6. Werre JLR. Nigerian lowland ecoregion: wild world report. 2001. Available from: http://www.worldwildlife.org/wildworld/profiles/terrestrial/ at/at0123_full.html\#just. Accessed May 25, 2008.

7. Greengrass EJ. A survey of chimpanzees in south-west Nigeria. 2006. Available from: http://data.cameroun-foret.com/system/files/18_13_132. pdf. Accessed August 12, 2013.

8. Mengistu DA, Salami AT. Application of remote sensing and GIS inland use/land cover mapping and change detection in a part of south western Nigeria. Afr J Environ Sc Technol. 2007;1:99-109.

9. Ikemeh RA. Survey of the Omo-Oluwa-Shasha forest complex, south western Nigeria: a preliminary report. Lagos: Nigerian Conservation Foundation; 2007.

10. Oates JF, Ikemeh RA, Ogunsesan AA, Bergl RA. A survey of the rainforests in Ogun, Ondo and Osun States in south-western Nigeria to assess options for sustainable Conservation. Nigerian Conservation Foundation. Lagos. 2008.

11. Ikemeh RA. Status of the Idanre Forest Reserve in Ondo State, Nigeria. Lagos: Leventis Foundation Nigeria; 2009.

12. Ojo LO. The fate of a tropical rainforest in Nigeria: a sector of Omo Forest Reserve. Global Nest. 2004;6:116-130.
13. BBC News. Nigeria: facts And figures. 2007. Available from: http:// news.bbc.co.uk/2/hi/africa/6508055.stm. Accessed August 12, 2013.

14. Green AA. Reconnaissance survey of Omo Forest Reserve: recommendations concerning chimpanzees, elephants and environmental protection. Lagos: Nigerian Forest Elephant and Wildlife Group; 2001.

15. Okali D, Eyog-Matig O. Rain forest management for wood production in West and Central Africa: lessons learnt on sustainable forest management in Africa. 2004. Available from: http://www.bioversityinternational.org/fileadmin/bioversityDocs/About_Us/Hosted_Services/ Rain_Forest_Management_for_Wood_Production.pdf. Accessed August 12, 2013.

16. Fuwape JA, Akindele SO, Adekunle VA. Forest management and forest landscapes in Nigeria: landscape ecology. Florence: Accademia Italiana di Scienze Forestali; 2006.

17. Ogunjemite BG, Agbelusi EA, Afolayan TA. Exploitation and regeneration rate in a commercially logged forest reserve, Ise Forest, Ekiti State. Environ Manag. 2005;2:70-77.

18. Azeez IO, Ikponmwonba OS, Popoola L, Amusa TO. Land use activities among forest environments' dwellers in Edo State, Nigeria: implications for livelihood and sustainable forest management. Int $J$ Soc For. 2010;3:164-187.

19. Food and Agriculture Organization. Global Forest Resources Assessment. Rome: FAO; 2005.

20. Ikemeh, R. A. (2013). Status Survey to determine the population viability of the Nigerian-Cameroon Chimpanzee in the Nigerian Lowland Rainforests of SW Nigeria: Ise forest reserve and the Idanre forest cluster. A report to the Ondo and Ekiti State Governments, SW/Niger Delta Forest Project, Nigeria. 60pp.

21. Ikemeh RA. A preliminary assessment of leopards in Okomu forest reserve, south western Nigeria. Benin City, Nigeria: Leventis Foundation; 2007.

22. Gonder MK, Disotell TR, Oates JF. New genetic evidence on the evolution of chimpanzee populations and implications for taxonomy. Int $J$ Primatol. 2006;27:1103-1117.

23. Ikemeh RA. Boundary demarcation/biodiversity survey in the Omo-Oluwa-Shasha forest complex. Lagos: Nigerian Conservation Foundation; 2009.

24. Gilbert N. Conservation's poverty reduction claims questioned. 2010 Available from: http://www.nature.com/news/2010/100506/full/ news.2010.222.html. Accessed August 12, 2013.

25. Fitzherbert EB, Struebig MJ, Morel A, et al. How will oil palm expansion affect biodiversity? Trends Ecol Evol. 2008;23:538-545.

26. Akinola S. 2006. Land use decree, forest administration and governance crises in Nigeria. Presented at: Promoting Land Administration and Good Governance 5th FIG Regional Conference; March 8-11, 2006; Accra, Ghana.

\section{Publish your work in this journal}

Research and Reports in Biodiversity Studies is an international, peerreviewed, open access journal publishing original research, reports, reviews and commentaries on all areas of biodiversity research. The manuscript management system is completely online and includes a

\section{Dovepress}

very quick and fair peer-review system. Visit http://www.dovepress.com/ testimonials.php to read real quotes from published authors. 